\title{
Successional leaf traits of monsoon evergreen broad-leaved forest, Southwest China
}

Wande Liu ${ }^{(1-2)}$
Jianrong Su

\section{Introduction}

Plant traits are biological characteristics of plant species that respond to the dominant processes in an ecosystem (Lavorel et al. 1997). Plant traits are defined characteristics that relate to plant species' patterns of establishment, growth and resource allocation. This includes plant evolutionary response to abiotic conditions and interactions with other species (Clark et al. 2012, Reich et al. 2003). Therefore, plant traits strongly influence plant fitness and performance (McGill et al. 2006). Plant traits can also be used as indicators of the mechanisms by which species affect ecosystem properties and processes (Suding et al. 2008). For example, specific leaf area (SLA), one of the most widely accepted key traits, has been proven to strongly correet al. 2002) and was one of the major contributors to an axis of resource capture, usage and availability. Leaf nitrogen ( $\left.N_{\text {mass }}\right)$ and phosphorus $\left(P_{\text {mass }}\right)$ concentrations can reflect plant and soil nutrient status, and influence vegetation composition (Güselate with relative growth rate (Vendramini

\begin{abstract}
Understanding the variation of functional traits of plant species along forest successional gradients may provides useful insights into community assemblages. However, species performance during forest succession is controversial. We explored the variation of leaf traits along a forest succession by exam ining ten leaf traits in four successional stages in a monsoon evergreen broadleaved forest in Southwest China. Results showed significant differences in all leaf traits except leaf area and leaf carbon content among the successional stages. Five leaf traits were highly correlated to successional stage, while the first principal component showed no correlation with successional stage. The first principal component accounted for $56.1 \%$ of the total variation in all ten leaf traits. Almost $50 \%$ of the relationships between leaf traits differed along the examined successional gradient, indicating that leaf traits were affected by the successional stage.
\end{abstract}

Keywords: Specific Leaf Area, Leaf Chemistry, Maximum Photosynthesis, Successional Stage, Monsoon Evergreen Broadleaved Forest well 2004). Leaf $N_{\text {mass }}$ to $P_{\text {mass }}$ ratios are determined by the uptake and loss of $\mathrm{N}$ and $\mathrm{P}$ and are useful in assessing $\mathrm{N}$ versus $\mathrm{P}$ limitation to primary production in terrestrial ecosystems (Han et al. 2005). Plant traits provide important information about ecological processes and improve our understanding of the mechanisms behind those processes (Garnier et al. 2004), especially forest succession (Kahmen \& Poschlod 2004).

The advantage of utilizing plant traits is that different vegetation types can be directly compared with specific processes, resulting in the extraction of general trends (Díaz \& Cabido 2001). This allows the prediction of vegetation dynamics by using plant trait responses (Díaz \& Cabido 2001). Furthermore, plant trait responses provide insight into the mechanisms underlying successional processes and the basis for thorough experimental studies on those mechanisms involved. Trait-based studies have been used successfully to evaluate complex ecosystem responses to human disturbance occurring in grasslands
(1) Research Institute of Resources Insect, Chinese Academy of Forestry, Kunming 650224 (China); (2) Puer Forest Eco-system Research Station, State Forestry Bureau, Kunming 650224 (China)

@ Jianrong Su (jianrongsu@vip.sina.com)

Received: Mar 08, 2016 - Accepted: Nov 18, 2016

Citation: Liu W, Su J (2017). Successional leaf traits of monsoon evergreen broad-leaved forest, Southwest China. iForest 10: 391-396. - doi: 10.3832/ifor2045-009 [online 2017-03-16]
(Mládek et al. 2010) and forest ecosystems (Aubin et al. 2007).

The aim of this study is to determine how plant traits relate to successional stages and how plant traits change throughout succession. We selected the 20 most abundant plant species in four successional stages of 15, 30, 40-yr-old forest and oldgrowth forest (older than 80 years) of monsoon evergreen broad-leaved forests in Southwest China. Ten morphological and physiological leaf traits were used to evaluate variations and correlations between successional stages. We asked two main research questions: (1) are different leaf traits related to different successional stages? (2) If so, how do these relationships change with successional stage?

\section{Materials and methods}

\section{Study sites}

The study was conducted in a monsoon evergreen broad-leaved forest in the Taiyang river provincial nature reserve $\left(22^{\circ}\right.$ $\left.32^{\prime}-22^{\circ} 37.8^{\prime} \mathrm{N}, 101^{\circ} 2.6^{\prime}-101^{\circ} 18^{\prime} \mathrm{E}\right)$ and the forest farm of the Vocational Education center of Pu'er $\left(22^{\circ} 43.2^{\prime}-22^{\circ} 45^{\prime} \mathrm{N}, 100^{\circ}\right.$ $\left.55.8^{\prime}-100^{\circ} 57^{\prime} \mathrm{E}\right)$ in the Pu'er region, Yunnan Province, China. The elevation of Taiyang river provincial nature reserve ranges from 585 to $1707 \mathrm{~m}$ a.s.l., with a mean annual temperature (from 2000 to 2010) of $17.7{ }^{\circ} \mathrm{C}$ and mean annual rainfall (from 2000 to 2010) of $1535 \mathrm{~mm}$, which occurs mainly between May and October. The elevation of the forest farm of the Vocational Education center of Pu'er ranges from 1142 to $1468 \mathrm{~m}$ a.s.l., with a mean annual temperature (from 2000 to 2010) of $17.7{ }^{\circ} \mathrm{C}$ and mean annual rainfall 
Tab. 1 - Environmental factors of the four successional stages. $(N)$ : soil nitrogen contents ( $\left.\mathrm{g} \mathrm{kg}^{-1}\right)$; $(P)$ : soil phosphorus contents $\left(\mathrm{g} \mathrm{kg}^{-1}\right)$; $(C)$ : soil carbon contents $\left(\mathrm{g} \mathrm{kg}^{-1}\right)$. Different letters in the same row indicate significant differences after Bonferroni's post-hoc test $(\mathrm{p}<0.05)$.

\begin{tabular}{|c|c|c|c|c|}
\hline \multirow{2}{*}{ Leaf traits } & \multicolumn{4}{|c|}{ Successional stages } \\
\hline & 15-yr-old & 30-yr-old & 40 -yr-old & Old-growth \\
\hline Elevation (m) & $1612 \pm 2^{a}$ & $1369 \pm 5^{b}$ & $1349 \pm 5^{b}$ & $1383 \pm 123^{a b}$ \\
\hline Slope (deg) & $20.0 \pm 1.2^{\mathrm{a}}$ & $19.7 \pm 3.9^{a}$ & $18.3 \pm 4.4^{\mathrm{a}}$ & $18.3 \pm 6.0^{a}$ \\
\hline$N\left(\mathrm{~g} \mathrm{~kg}^{-1}\right)$ & $2.07 \pm 0.14^{\mathrm{a}}$ & $1.03 \pm 0.13^{b}$ & $1.33 \pm 0.11^{b c}$ & $1.99 \pm 0.37^{a c}$ \\
\hline$P\left(\mathrm{~g} \mathrm{~kg}^{-1}\right)$ & $0.35 \pm 0.00^{a b}$ & $0.23 \pm 0.02^{a}$ & $0.30 \pm 0.03^{a}$ & $0.42 \pm 0.06^{b}$ \\
\hline$C\left(\mathrm{~g} \mathrm{~kg}^{-1}\right)$ & $49.8 \pm 3.9^{a}$ & $31.2 \pm 3.2^{b}$ & $30.1 \pm 3.4^{b}$ & $45.8 \pm 8.3^{\mathrm{ab}}$ \\
\hline $\mathrm{pH}$ & $4.54 \pm 0.06^{a}$ & $4.82 \pm 0.08^{a}$ & $4.80 \pm 0.10^{a}$ & $5.09 \pm 0.25^{a}$ \\
\hline Soil water content (\%) & $24.4 \pm 4.18^{a}$ & $27.6 \pm 2.94^{a}$ & $27.2 \pm 2.18^{a}$ & $32.2 \pm 0.89^{b}$ \\
\hline
\end{tabular}

(from 2000 to 2010) of $1535 \mathrm{~mm}$ which occurs mainly between May and October. The monsoon evergreen broad-leaved forest is the dominant vegetation type in the two study sites. However, parts of the forest in the forest farm of the Vocational Education center of Pu'er were logged in the $20^{\text {th }}$ century, resulting in four succes-

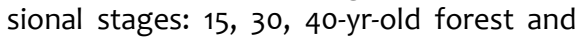
old-growth forest ( $>80$ years). The 15 -yr-old forest has a high stand density of relatively small trees. Lithocarpus fenestratus, Helicia nilagirica, Litsea cubeba, Castanopsis echinocarpa and Schimawallichii were the main canopy trees. The dominant understory species were Canthium horridum, Dalbergia rimosa, Scleria herbecarpa and Pteridophyta. In the 30 and 40-yr-old forest, stand density was lower compared with the 15-yrold forest. The mean plant height was higher with numerous trees diameter at breast height $(\mathrm{DBH})>20 \mathrm{~cm}$. The main canopy trees included C. echinocarpa, L. fenestratus, Aporusa villosa, Machilus robusta and $C$. hystrix. The dominant understory species were Canthium horridum, Ficus hirta and Pteridophyta. In the old-growth forest, the dominant tree species were $C$. echinocarpa and C.hystrix, with the understory containing Ardisia maculosa, Fordia

microphylla, S. herbecarpa and Pteridophyta. Pteridophyta and Orchidaceae grow epiphytically on stems or the forest canopy occurring frequently in all the surveyed forest types. In addition, rich buttressed trees and lianas formed an important characteristic of monsoon evergreen broad-leaved forests in the Pu'er region.

\section{Data collection}

Three $30 \times 30 \mathrm{~m}$ plots were established in each of four successional stages, for a total of twelve plots. Each plot was located in a representative area of each successional stage with a minimum distance of $100 \mathrm{~m}$ from any major trail. The minimum distance between any two plots was $200 \mathrm{~m}$. All plots were established on similar terrain. Each plot was divided into thirty-six 5 $\times 5 \mathrm{~m}$ subplots. All living stems $>1 \mathrm{~cm}$ diameter (DBH) in the subplots were tagged, identified to species, numbered, and their $\mathrm{DBH}$ and height were recorded. In each plot we sampled ten individual trees per species taking two leaves from each individual tree. The 20 most abundant species were sampled. This resulted in more than $70 \%$ of the total individuals in each successional stage (15-yr-old forest: $72.4 \%$; 30-yrold forest: $83.6 \%$; 40 -yr-old forest: $83.5 \%$;

Tab. 2 - Leaf traits at the four successional stages. (LA): leaf area $\left(\mathrm{cm}^{2}\right)$; (SLA): specific leaf area $\left(\mathrm{m}^{2} \mathrm{~kg}^{-1}\right)$; $\left(N_{\text {mass }}\right)$ : leaf nitrogen contents (mass basis, $\left.\mathrm{g} \mathrm{kg}^{-1}\right) ;\left(P_{\text {mass }}\right)$ : leaf phosphorus contents (mass basis, $\left.\mathrm{g} \mathrm{kg}^{-1}\right) ;\left(N_{\text {mass }}: P_{\text {mass }}\right)$ : the ratio of leaf nitrogen contents (mass basis) to leaf phosphorus contents (mass basis); (LCC): leaf carbon contents ( $g$ $\left.\mathrm{kg}^{-1}\right)$; $\left(N_{\text {area }}\right)$ : leaf nitrogen contents (area basis, $\left.\mathrm{g} \mathrm{m}^{-2}\right)$; $\left(P_{\text {area }}\right)$ : leaf phosphorus contents (area basis, $\left.\mathrm{g} \mathrm{m}^{-2}\right)$; $\left(A_{\text {mass }}\right)$ : maximum photosynthesis (mass basis, $\left.\mathrm{nmol} \mathrm{g}^{-1} \mathrm{~s}^{-1}\right)$; $\left(A_{\text {area }}\right)$ : maximum photosynthesis (area basis, $\mu \mathrm{mol} \mathrm{m}^{-2} \mathrm{~s}^{-1}$ ). Different letters in the same row indicate significant differences after Bonferroni's post-hoc test $(p<0.05)$.

\begin{tabular}{|c|c|c|c|c|}
\hline \multirow{2}{*}{ Leaf traits } & \multicolumn{4}{|c|}{ Successional stages } \\
\hline & 15-yr-old & 30-yr-old & 40-yr-old & Old-growth \\
\hline LA $\left(\mathrm{cm}^{2}\right)$ & $40.6 \pm 5.2^{a}$ & $48.6 \pm 6.3^{a}$ & $41.5 \pm 4.8^{a}$ & $44.8 \pm 4.9^{a}$ \\
\hline $\operatorname{SLA}\left(\mathrm{m}^{2} \mathrm{~kg}^{-1}\right)$ & $21.5 \pm 2.0^{a}$ & $17.6 \pm 0.9$ ab & $15.7 \pm 0.6^{a b}$ & $15.1 \pm 0.7^{b}$ \\
\hline$N_{\text {mass }}\left(\mathrm{g} \mathrm{kg}^{-1}\right)$ & $20.5 \pm 1.5^{a}$ & $14.8 \pm 0.6^{b}$ & $14.3 \pm 0.6^{b}$ & $19.2 \pm 1.1^{\mathrm{a}}$ \\
\hline$P_{\text {mass }}\left(\mathrm{g} \mathrm{kg}^{-1}\right)$ & $1.64 \pm 0.22^{a}$ & $1.04 \pm 0.08^{a b}$ & $0.85 \pm 0.04^{b}$ & $1.10 \pm 0.04^{\mathrm{a}}$ \\
\hline$N_{\text {mass }}: P_{\text {mass }}$ & $14.10 \pm 0.80^{\mathrm{a}}$ & $15.10 \pm 0.40^{\mathrm{a}}$ & $17.60 \pm 0.60^{b}$ & $17.80 \pm 0.80^{b}$ \\
\hline LCC $\left(\mathrm{g} \mathrm{kg}^{-1}\right)$ & $465.10 \pm 28.2^{\mathrm{a}}$ & $472.70 \pm 37.6^{a}$ & $465.80 \pm 37.2^{\mathrm{a}}$ & $468.90 \pm 34.3^{a}$ \\
\hline$N_{\text {area }}\left(\mathrm{g} \mathrm{m}^{-2}\right)$ & $1.02 \pm 0.29$ ac & $0.79 \pm 0.23^{b}$ & $0.93 \pm 0.17^{\mathrm{ab}}$ & $1.41 \pm 0.67^{c}$ \\
\hline$P_{\text {area }}\left(\mathrm{g} \mathrm{m}^{-2}\right)$ & $0.07 \pm 0.02 \mathrm{ac}$ & $0.06 \pm 0.02 \mathrm{ab}$ & $0.05 \pm 0.01^{b}$ & $0.08 \pm 0.03^{c}$ \\
\hline$A_{\text {mass }}\left(\mathrm{nmolg}^{-1} \mathrm{~s}^{-1}\right)$ & $4.70 \pm 0.04^{a}$ & $4.55 \pm 0.02^{b c}$ & $4.49 \pm 0.02^{b}$ & $4.61 \pm 0.11^{\text {ac }}$ \\
\hline$A_{\text {area }}\left(\mu \mathrm{mol} \mathrm{m} \mathrm{m}^{-2} \mathrm{~s}^{-1}\right)$ & $1.77 \pm 0.02^{a}$ & $1.68 \pm 0.01^{b}$ & $1.71 \pm 0.01^{\mathrm{b}}$ & $1.81 \pm 0.02^{\mathrm{a}}$ \\
\hline
\end{tabular}

old-growth forest: $74.2 \%)$. Five soil samples were collected from each plot and used to analyze the physical and chemical soil properties (Tab. 1). Elevation and slope of each plot were also recorded (Tab. 1).

Ten easy-to-measure leaf traits were selected to reflect the processes of forest dynamics. Three traits were related to energy (LA: leaf area; $A_{\text {mass }}$ : maximum photosynthesis based on mass; $A_{\text {area: }}$ : maximum photosynthesis based on area), five traits were related to nutrient $\left(N_{\text {mass }}\right.$ : leaf $\mathrm{N}$ content based on mass; $P_{\text {mass }}$ : leaf $\mathrm{P}$ content based on mass; $N_{\text {mass }}: P_{\text {mass }} ; N_{\text {area: }}$ leaf $N$ content based on area; $P$ area: leaf $P$ content based on area), and two traits were linked to plant growth (SLA; LCC: leaf C content). LA was measured with a portable area meter (Li-Cor $3000 \mathrm{~A}^{\circledast}$, Lincoln, NE, USA). Leaves were dried at $70{ }^{\circ} \mathrm{C}$ to a constant weight (Albayrak \& Çamas 2007) and weighed (dry leaf weight, DLW) for SLA determination (SLA = LA/DLW). All leaves from the same species in the same plot were pooled for chemical analysis. $N_{\text {mass }}$ was measured using an elemental analyzer (NCS2500 ${ }^{\oplus}$, Carlo Erba Instruments, Milan, Italy). $P_{\text {mass }}$ was determined using inductively coupled plasma emission spectroscopy (Southwest Forestry University, China). The ratio of $N_{\text {mass }}: P_{\text {mass }}$ was also calculated. LCC was determined using an elemental analyzer (model EA $1108^{\circledR}$, Carlo Erba Instruments, Milan, Italy). Area- and mass-based traits can be inter-converted via SLA (for example, $N_{\text {area }}=N_{\text {mass }} / S L A, P_{\text {area }}=$ $P_{\text {mass }} /$ SLA - Wright et al. 2004), which can be used to estimate $A_{\text {mass }}$ and $A_{\text {area. }}$. $A_{\text {mass }}$ was estimated from SLA and $N_{\text {mass, }}$, while $A_{\text {area }}$ was estimated using SLA and $N_{\text {area }}$, using the multiple regression model proposed by Wright et al. (2004).

\section{Data analysis}

We first calculated the means of LA and SLA for each species in each successional stage and then analyzed these mean values using one-way analyses of variance (ANO$\mathrm{VA}$ ). Differences in leaf traits and the physical and chemical properties of soil for each successional stage were tested with ANOVA. Further analyses using Bonferroni's post-hoc tests (Student-NewmansKeuls) were performed where required. Dependent variables were $\log _{10}$ transformed where necessary to conform to homoscedasticity assumptions.

For multivariate analyses we used the indirect ordination method. Principal Components Analysis (PCA) was conducted on the leaf traits using the software PC Ord ${ }^{\circledR}$ ver. 5.02 (MJM Software Design, Gleneden Beach, OR, USA). To detect relationships between successional stage and leaf traits we applied the Spearman's correlation analysis with the leaf traits and PC1 and PC2. Regression analysis was conducted when a significant correlation occurred.

Standardized major axis (SMA) analysis was used to describe the relationship between each possible pairwise combination 
Fig. 1 - Principal Components Analysis (PCA) of the ten leaf traits. (LA): leaf area $\left(\mathrm{cm}^{2}\right)$; (SLA): specific leaf area $\left(\mathrm{m}^{2} \mathrm{~kg}^{-1}\right)$; (NP): the ratio of leaf nitrogen contents (mass basis) to leaf phosphorus contents (mass basis); $\left(N_{\text {mass }}\right)$ : leaf nitrogen contents (mass basis, $\left.\mathrm{g} \mathrm{kg}^{-1}\right)$; $\left(P_{\text {mass }}\right)$ : leaf phosphorus contents (mass basis, $\left.\mathrm{g} \mathrm{kg}^{-1}\right)$; ( LCC): leaf carbon contents ( $\left.\mathrm{g} \mathrm{kg}^{-1}\right)$; $\left(N_{\text {area }}\right)$ : leaf nitrogen contents (area basis, $\left.\mathrm{g} \mathrm{m}^{-2}\right)$; $\left(P_{\text {area }}\right)$ : leaf phosphorus contents (area basis, $\left.\mathrm{g} \mathrm{m}^{-2}\right)$; $\left(A_{\text {mass }}\right)$ : maximum photosynthesis (mass basis, $\left.n m o l g^{-1} s^{-1}\right) ;\left(A_{\text {area }}\right)$ : maximum photosynthesis (area basis, $\mu \mathrm{mol} \mathrm{m} \mathrm{m}^{-2} \mathrm{~s}^{-1}$.

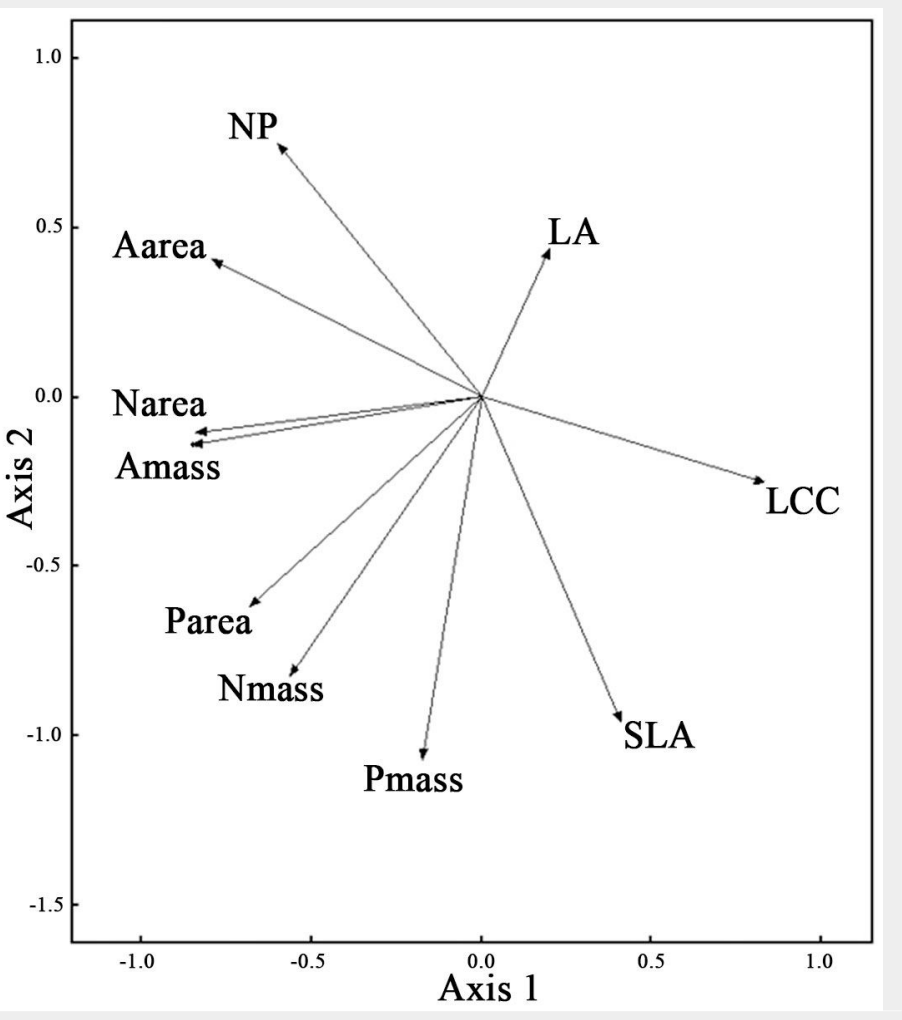

of leaf traits. SMA has become a standard procedure in leaf trait studies where bivariate relationships are quantified between variables that are measured with error (Warton et al. 2006). Our aim was to estimate the line of best-fit describing the bivariate scatter of two traits. SMA regression is used to estimate lines with greater precision than major axis regression (Warton et al. 2006). On log-log axes, SMA regression describes the best-fit scaling relationship between pairs of traits. SMA regression analyses were performed using the free software package SMATR ver. 2.0 (Falster et al. 2006). Other statistical computations were carried out with SPSS ${ }^{\oplus}$ ver. 17.0 (SPSS Inc., Chicago, IL, USA). All tests were carried out at a significance level of a $=0.05$.

\section{Results}

Leaf traits variations with successional stages

All leaf traits except two (LA and LCC) were significantly different among successional stages. As vegetation recovered, SLA decreased (Tab. 2). Conversely, $N_{\text {mass }}$ : $P_{\text {mass }}$ was positively associated with forest succession (Tab. 2). The 15-yr-old forest had the highest $N_{\text {mass }}, A_{\text {mass }}$ and $P_{\text {mass }}$. The 40-yrold forest had the lowest $N_{\text {mass }}$ and $P_{\text {mass }}$. The $N_{\text {area }}, P_{\text {area }}$ and $A_{\text {area }}$ were the highest in the old-growth forest and lowest in 30-yrold and 40-yr-old forests (Tab. 2).

\section{Correlations between leaf traits and successional stage}

The PCA of the 10 measured traits captured $90.6 \%$ of the variance in two principal components, with the first axis accounting for $56.1 \%$ (eigenvalue $=2.929$ - Fig. 1). The first axis mainly described resource use and was positively associated with LA, SLA and LCC and negatively associated with $N_{\text {area, }}$ $N_{\text {mass }}, P_{\text {area }}, A_{\text {mass }}$ and $A_{\text {area. }}$. PC1 was unrelated to successional stage (Tab. 3). The second axis (accounting for $34.5 \%$ of the total variance) mainly described resource availability and was positively associated with LA, $N_{\text {mass }}: P_{\text {mass }}$ and $A_{\text {area }}$ and negatively associated with SLA, $N_{\text {mass }}, P_{\text {mass }}$ and $P_{\text {area }}$ PC2 was unrelated to successional stage (Tab. 3 ).

Significant correlations were found between most leaf traits and successional stage. SLA, $P_{\text {mass }}$ and $A_{\text {mass }}$ were strongly

negatively correlated to successional stage (Tab. 3). In contrast, $N_{\text {mass }}: P_{\text {mass }}$ and $N_{\text {area }}$ were positively correlated to successional stage (Tab. 3). The best-fitting regression models of the relationships between leaf traits and the successional stage are shown in Fig. 2. However, $N_{\text {mass }}, P_{\text {area }}$ and $A_{\text {area }}$ were unrelated to successional stage, although they showed significant differences between different stages. Likewise, LA and LCC were uncorrelated to successional stage.

\section{Relationship between plant traits in different successional stages}

The relationship between SLA and LA,

Tab. 3 - Correlations between leaf traits and successional stage. (LA): leaf area $\left(\mathrm{cm}^{2}\right)$; (SLA): specific leaf area $\left(\mathrm{m}^{2} \mathrm{~kg}^{-1}\right)$; $\left(N_{\text {mass }}\right)$ : leaf nitrogen contents (mass basis, $\left.\mathrm{g} \mathrm{kg}^{-1}\right)$; $\left(P_{\text {mass }}\right)$ : leaf phosphorus contents (mass basis, $\left.g \mathrm{~kg}^{-1}\right)$; $\left(N_{\text {mass }}: P_{\text {mass }}\right)$ : the ratio of leaf nitrogen contents (mass basis) to leaf phosphorus contents (mass basis); (LCC): leaf carbon contents $\left(\mathrm{g} \mathrm{kg}^{-1}\right)$; $\left(N_{\text {area }}\right)$ : leaf nitrogen contents (area basis, $\left.\mathrm{g} \mathrm{m} \mathrm{m}^{-2}\right)$; $\left(P_{\text {area }}\right)$ : leaf phosphorus contents (area basis, $\left.\mathrm{g} \mathrm{m}^{-2}\right)$; $\left(A_{\text {mass }}\right)$ : maximum photosynthesis (mass basis, $\left.\mathrm{nmol} \mathrm{g}^{-1} \mathrm{~s}^{-1}\right)$; $\left(A_{\text {area }}\right)$ : maximum photosynthesis (area basis, $\mu \mathrm{mol} \mathrm{m} \mathrm{m}^{-2} \mathrm{~s}^{-1}$ ).

\begin{tabular}{|c|c|c|}
\hline Leaf traits & Pearson's correlation & $P$ \\
\hline LA $\left(\mathrm{cm}^{2}\right)$ & 0.063 & 0.580 \\
\hline $\operatorname{SLA}\left(\mathrm{m}^{2} \mathrm{~kg}^{-1}\right)$ & $-0.373^{* *}$ & 0.001 \\
\hline$N_{\text {mass }}\left(\mathrm{g} \mathrm{kg}^{-1}\right)$ & -0.099 & 0.381 \\
\hline$P_{\text {mass }}\left(\mathrm{g} \mathrm{kg}^{-1}\right)$ & $-0.338^{* *}$ & 0.002 \\
\hline$N_{\text {mass }}: P_{\text {mass }}$ & $0.460^{* *}$ & 0.000 \\
\hline LCC $\left(\mathrm{g} \mathrm{kg}^{-1}\right)$ & 0.015 & 0.896 \\
\hline$N_{\text {area }}\left(\mathrm{g} \mathrm{m}^{-2}\right)$ & $0.325^{* *}$ & 0.003 \\
\hline$P_{\text {area }}\left(\mathrm{g} \mathrm{m}^{-2}\right)$ & 0.086 & 0.446 \\
\hline$A_{\text {mass }}\left(\mathrm{nmolg}^{-1} \mathrm{~s}^{-1}\right)$ & $-0.244^{*}$ & 0.029 \\
\hline$A_{\text {area }}\left(\mu \mathrm{mol} \mathrm{m} \mathrm{m}^{-2} \mathrm{~s}^{-1}\right)$ & 0.202 & 0.072 \\
\hline PC1 & -0.673 & 0.327 \\
\hline PC2 & 0.704 & 0.248 \\
\hline
\end{tabular}




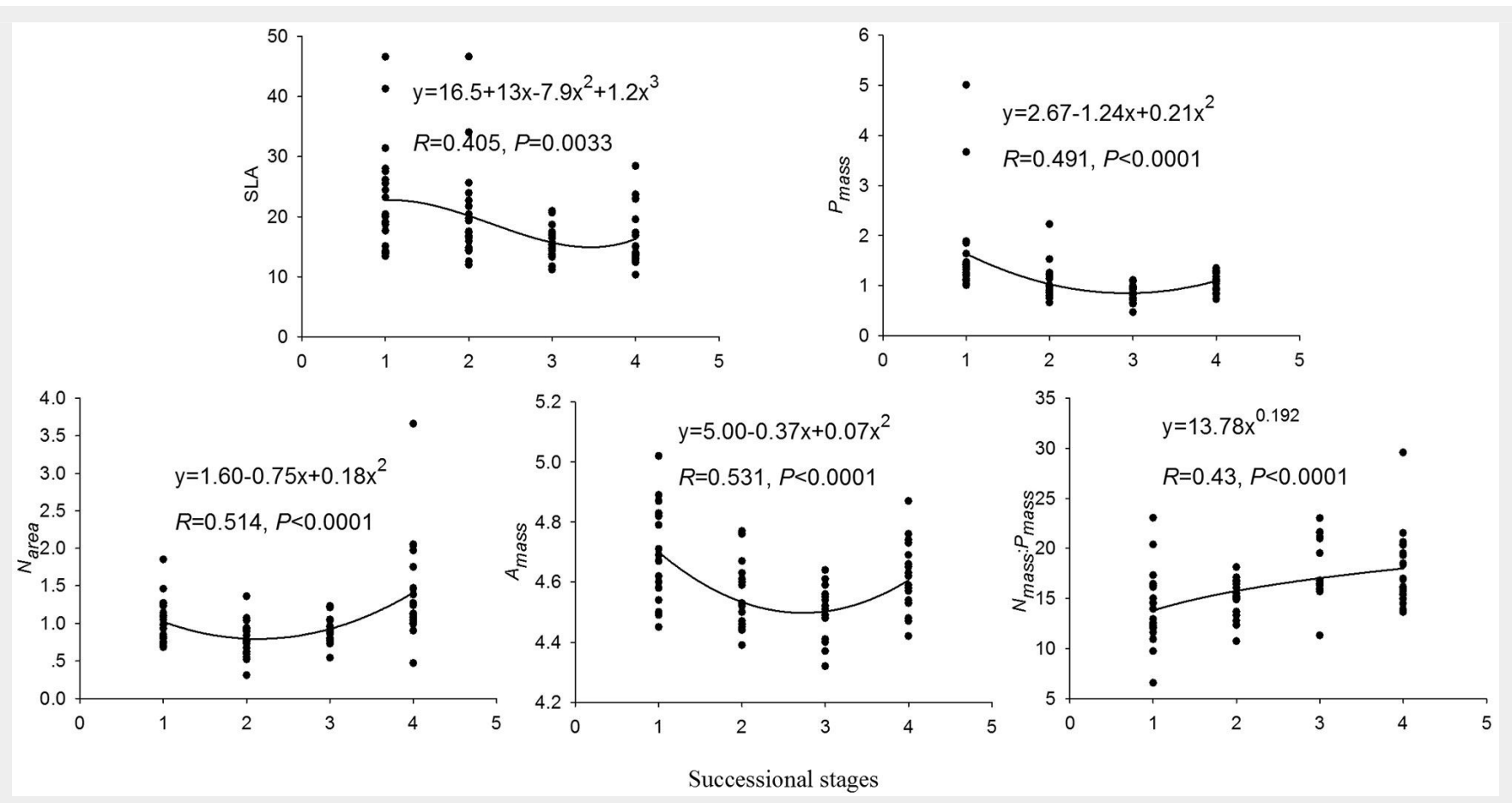

Fig. 2 - Regression analysis between successional stage and leaf traits. (SLA): specific leaf area $\left(\mathrm{m}^{2} \mathrm{~kg}^{-1}\right)$; $\left(\mathrm{N}_{\text {mass }}\right)$ : leaf nitrogen contents (mass basis, $\left.\mathrm{g} \mathrm{kg}^{-1}\right)$; $\left(P_{\text {mass }}\right)$ : leaf phosphorus contents (mass basis, $\left.\mathrm{g} \mathrm{kg}^{-1}\right)$; $\left(\mathrm{N}_{\text {area }}\right)$ : leaf nitrogen contents $\left(\right.$ area basis, $\left.\mathrm{g} \mathrm{m}^{-2}\right)$; $\left(A_{\text {mass }}\right)$ : maximum photosynthesis (mass basis, nmol g-1 $\left.\mathrm{s}^{-1}\right)$; successional stages (x-axis): (1) 15-yr-old; (2) 30-yr-old; (3) 40-yr-old; (4) old-growth forests ( $>80$ years).

$N_{\text {mass }}: P_{\text {mass }}$ and LCC were non-significant in all successional stages except for $N_{\text {mass }}: P_{\text {mass }}$ in the 30-yr-old forest (negative association, $P=0.000$ ) and LCC in the 15-yr-old forest (negative association, $P=0.012$ ). The SMA slopes for the SLA - LA, SLA - $N_{\text {mass }}$ : $P_{\text {mass }}$ and SLA - LCC relationships were homogeneous among all successional stages (Tab. S3 in Supplementary material). SLA was positively associated with $N_{\text {mass }}$ in all successional stages except the 30-yr-old forest $(P=0.100)$ and with $P_{\text {mass }}$ in all four successional stages $(P<0.05)$. The SMA slopes for the SLA - $N_{\text {mass }}$ and SLA - $P_{\text {mass }}$ relationships were homogeneous among successional stages. SLA was negatively associated with $N_{\text {area }}, A_{\text {mass }}$ and $A_{\text {area }}$ in all successional stages $(P<0.05)$. The SMA slopes for the SLA - $N_{\text {area }}$, SLA - $A_{\text {mass }}$ and SLA - $A_{\text {area }}$ relationships were heterogeneous among successional stages, the greatest SMA slopes were in the 15 -yr-old forest for the SLA - $N_{\text {area }}$ and the SLA - $A_{\text {mass }}$ relationships and in the 40-yr-old forest for the SLA - $A_{\text {area }}$ relationships (Tab. S3 in Supplementary material). The SMA slope for the SLA - $P_{\text {area }}$ relationship was homogeneous among successional stages (Tab. S3).

The SMA slope for the $L A-N_{\text {mass }}: P_{\text {mass }}, L A$ - $N_{\text {mass, }}$ LA - $P_{\text {mass }}$, LA - LCC, LA - N $N_{\text {area }}$, LA $P_{\text {area }}$ and LA $-A_{\text {mass }}$ relationships were homogeneous among successional stages $(P>0.05)$, but the SMA slope for the LA $A_{\text {area }}$ was heterogeneous among successional stages with the highest slope in the 40-yr-old forest.

The SMA slope for the $N_{\text {mass }}: P_{\text {mass }}-N_{\text {mass }}$ and $N_{\text {mass }}: P_{\text {mass }}-P_{\text {mass }}$ relationships were ho- mogeneous among successional stages ( $P$ $>0.05$ ), but the SMA slope for the $N_{\text {mass: }}$ : $P_{\text {mass }}-$ LCC, $N_{\text {mass }}: P_{\text {mass }}-N_{\text {areaa }}, N_{\text {mass }}: P_{\text {mass }}-$ $P_{\text {area }}, N_{\text {mass }}: P_{\text {mass }}-A_{\text {mass }}$ and $N_{\text {mass }}: P_{\text {mass }}-A_{\text {area }}$ were heterogeneous among successional stages. The 15-yr-old forest had the highest SMA slope in the SLA - $N_{\text {area }}$ In the $N_{\text {mass }}$ : $P_{\text {mass }}-$ LCC, $N_{\text {mass }}: P_{\text {mass }}-N_{\text {area }}, N_{\text {mass }}: P_{\text {mass }}-P_{\text {area }}$ and $N_{\text {mass }}: P_{\text {mass }}-A_{\text {mass }}$ relationships, the 40yr-old forest had the highest SMA slope in the $N_{\text {mass }}: P_{\text {mass }}-A_{\text {area }}$ relationship (Tab. S3).

The SMA slope for the LCC $-P_{\text {mass }}$ LCC $N_{\text {area, }}$ LCC $-P_{\text {area }}$ LCC $-A_{\text {mass }}, N_{\text {area }}-P_{\text {area }}, P_{\text {area }}-$ $A_{\text {mass }}$ and $P_{\text {area }}-A_{\text {area }}$ relationships were homogeneous among successional stages $(P>0.05)$. However, all the SMA slope for the $N_{\text {mass }}-P_{\text {mass }}, N_{\text {mass }}-L C C, N_{\text {mass }}-N_{\text {area }}, N_{\text {mass }}$ - $P_{\text {area }}, N_{\text {mass }}-A_{\text {mass }}, N_{\text {mass }}-A_{\text {area }}$ LCC $-A_{\text {area }}$, $P_{\text {mass }}-N_{\text {area }}, P_{\text {mass }}-P_{\text {area }}, P_{\text {mass }}-A_{\text {mass }}, P_{\text {mass }}-$ $A_{\text {area }}, N_{\text {area }}-A_{\text {mass }}, N_{\text {area }}-A_{\text {area }}$ and $A_{\text {mass }}-A_{\text {area }}$ relationships were heterogeneous among successional stages (Tab. S3 in Supplementary material).

\section{Discussion}

Our analysis of a chronosequence of successional stages in a monsoon evergreen broad-leaved forest showed that species with relatively high rates of photosynthesis and leaf traits related to fast growth (high SLA) were progressively replaced by species with low SLA over time. This pattern is consistent with the shift of species along the leaf economics spectrum, as documented in other primary (Caccianiga et al. 2006) and secondary successional series (Chai et al. 2015, Garnier et al. 2004, Navas et al. 2010, Reich 1995). SLA is one of the most widely accepted key leaf traits (Hoffmann et al. 2005, Kraft et al. 2008) and is strongly linked to relative growth rate and resource use in plants (Vendramini et al. 2002). It is also a major contributor to resource capture, usage and availability (Funk \& McDaniel 2010, Westoby et al. 2002). Used as a proxy for relative growth rate of a species, SLA is positively related to resource richness (Westoby 1998, Wilson \& Thompson 1999). After mature trees are felled the priority of retaining resources decreases in forest gaps. Complex litter produced by early successional communities is shown to decompose more rapidly than litter produced by communities from more advanced successional stages (Garnier et al. 2004). Therefore, species with high SLA should increase in abundance as resources availability increases (Kahmen \& Poschlod 2004). With vegetation succession, the fast-growing, light-demanding species are progressively replaced by slow-growing, shade-tolerant species, which tend to conserve resources more efficiently as succession proceeds. It has been shown that slow-growing, shadetolerant species have low SLA (Funk \& McDaniel 2010), which may explain why SLA was the lowest in old-growth forests.

Nitrogen and phosphorus are essential nutrients and play an important role in plant growth, development and behavior. The circulation of nitrogen and phosphorus limit most terrestrial ecosystem processes (Aerts \& Chapin 2000). In this study $N_{\text {mass }}$, which generally co-varies with SLA (Wright et al. 2004), was higher in the initial and lat- 
ter stages of succession likely due to the consequences of the relatively low nutrient availability in the intermediate stages (Liu et al. 2010). This shows that, although $N_{\text {mass }}$ and SLA are positively correlated as part of the leaf economics spectrum, they can be partly decoupled, possibly to optimize $N_{\text {area }}$ and $A_{\text {mass }}$ (Wright et al. 2003). Previous studies have reported variable $\mathrm{N}$ patterns with succession including leaf $\mathrm{N}$ increases consistently with succession (Douma et al. 2012), non-significant shifts (Navas et al. 2010) and slightly negative shifts during the early stages of succession (Reich 1995). After tree felling operations, branches and leaves are usually left in situ. Decomposition of tree litter during the initial phase of succession has shown to result in the high concentrations of soil nutrients and thriving microbial communities (Douma et al. 2012). However, in old-growth forests, decomposition of litter generated by the forests themselves also increases soil nutrients. Unlike $N_{\text {mass }}, P_{\text {mass }}$ tended to decrease as succession proceeded. Our results are in agreement with previous studies (Chai et al. 2016). These difference in $N_{\text {mass }}$ and $P_{\text {mass }}$ use demonstrates the differences in life history strategy among plants during succession, and reflects the important fundamental niche axes along which the species are differentiated (Westoby et al. 2002). The high $P_{\text {mass }}$ indicates high photosynthetic capacity of the plant leaves and a fast-growing, light-demanding species with a high potential for successful establishment in forest gaps (Grotkopp \& Rejmanek 2007).

The $\mathrm{N}: \mathrm{P}$ ratio drives plant community structure and function, and is negatively related to growth rate (Elser et al. 2003). However, in the present study $N_{\text {mass }}: P_{\text {mass }}$ increased with succession, which is in agreement with a previous study (Chai et al. 2015). Two theories could explain this phenomenon. First, species differ in their optimal N:P ratios for growth and reproduction, with species-specific homeostasis achieved by nutrient-balancing mechanisms (Kay et al. 2005, He et al. 2008). Although the study sites all are in the Pu'er region, environmental filters only determine the possible species pool within a biogeographic region. Successional stage determines species composition and different species composition alone could lead to local-scale and biome-scale differences in $\mathrm{N}: \mathrm{P}$ ratios. Over $50 \%$ of species in this study were different among four successional stages (Tab. S2 in Supplementary material). Species with different biological properties have separate nutrient use strategies, resulting in different $\mathrm{N}: \mathrm{P}$ ratios among four successional stages. Second, regardless of species composition, different processes drive $\mathrm{N}$ and $\mathrm{P}$ availability in different communities. $P$ is mainly derived from weathering and leaching, which is a slow biogeochemical process and its availability in the soil reflects the physical and chemical characteristics of the local parent material. In contrast, many processes drive $\mathrm{N}$ availability (Aerts \& Chapin 2000), and $\mathrm{N}$ mineralization and release is more abundant than elemental P in litter (Güsewell 2004). Large differences exist in the availability and the uptake efficiency between elemental $\mathrm{N}$ and $\mathrm{P}$. Changes in environmental conditions and community structure affect the availability and uptake of $\mathrm{N}$ and $\mathrm{P}$ element in successional stages of evergreen broadleaved forest (Yan et al. 2008). This likely results in different $\mathrm{N}: \mathrm{P}$ ratios in different species. Moreover, although plant $\mathrm{N}$ and $\mathrm{P}$ concentrations co-vary consistently, when $\mathrm{N}$ and $\mathrm{P}$ sources differ, environmental conditions are extreme and the variability of nutrients storage by plants, a decoupling of leaf $\mathrm{N}$ and $\mathrm{P}$ appears. Based on numerous studies the threshold of foliar $\mathrm{N}: \mathrm{P}$ ratios are $<14$ and $>16$ for $\mathrm{N}$ and $\mathrm{P}$ limitation, respectively (Güsewell \& Gessner 2009, Matzek \& Vitousek 2009). In this study, $N_{\text {mass }}: P_{\text {mass }}$ ratios in the 40 -yr-old and the old-growth forest were $>16$, clearly indicating that $P$ was the main limiting factor in succession. Wardle et al. (2004) found that in the later stages of forest succession, productivity declines and $\mathrm{N}: \mathrm{P}$ ratios in the humic matter and fresh litter increase, suggesting that $P$ was the limiting factor in succession.

Significant differences in leaf area and leaf carbon content were not observed, but maximum photosynthesis (mass- and area-basis) was different between the four successional stages. The changes in maximum photosynthesis with forest succession point to the replacement of fast-growing species with slower growing species, which tend to conserve internal resources more efficiently as succession proceeds (Garnier et al. 2004). In early successional stages, the fast-growing species have higher maximum photosynthesis in order to obtain higher relative growth rate and rapid biomass gain. Carbon gain is maximized by the constant renewal of the leaf area in early succession, as new leaves have high levels of photosynthetic capacity (Navas et al. 2010). Low photosynthesis values may reflect shade adaptation (Waite \& Sack 2010) and relatively low nutrient availability in the intermediate successional stages (Liu et al. 2010). Conversely, in late successional stages carbon gain is maximized by the production of long-lived leaves, which have low photosynthetic capacity (Navas et al. 2010) and relatively high nutrient content.

The relationships between leaf traits in succession stages indicate that successional stage influences leaf characteristics. For SMA, over half of the regression slopes showed significant differences with forest succession. Although the same negative or positive relationship occurred for some trait pairs in all four successional stages, the SMA slope showed a significant difference with the greatest slope occurring in the old-growth or 15-yr-old forests. Although $P_{\text {mass }}$ and $A_{\text {mass }}$ co-vary consistently in the world-wide leaf economics spectrum (Wright et al. 2004), $P_{\text {mass }}$ was negatively associated to $A_{\text {mass }}$ in the 15 -yr-old, and was positively associated to $A_{\text {mass }}$ in the $30-y r-$ old, 40-yr-old forests and old-growth forest. Moreover, we found the relationship of 11 trait-pairs where the SMA slope showed a non-significant difference. For example, SLA was negatively associated to $N_{\text {mass }}: P_{\text {mass }}$ in the 15-yr-old, 30-yr-old and 40yr-old forests, but not in old-growth forest; LA were positively associated to $P_{\text {area }}$ in the 15-yr-old, 30-yr-old and 40-yr-old forests, but not in old-growth forest. The results indicate that covariation in leaf traits is not universal and will be affected by forest succession. As succession proceeds, fastgrowing species are progressively replaced by slow-growing species, which results in the differences in resource use and life history strategy and the changes in leaf trait relationships.

\section{Conclusions}

Although consistent changes of all leaf traits with succession were not observed, the mean trait values of eight out of ten leaf traits differed between the four successional stages. The SLA decreased as the vegetation recovered and $N_{\text {mass }}: P_{\text {mass }}$ was positively associated with forest succession. Meanwhile, five leaf traits were highly correlated to successional stage. SLA, $P_{\text {mass }}$ and $A_{\text {mass }}$ were strongly negatively correlated to successional stage and $N_{\text {mass }}: P_{\text {mass }}$ and $N_{\text {area }}$ were strongly positively correlated. Additionally, the SMA analysis showed that the relationship between leaf traits changes with succession. These results show that leaf traits are affected by forest succession and one or a combination of several leaf traits can determine successional stages in the monsoon evergreen broad-leaved forest.

\section{Acknowledgements}

LW carried out the field measurements and drafted the manuscript. SJ conceived the study and revised the manuscript. We are also very thankful to Damon Hartley and Zhen Yu for revising the English text. We would also like to thank Alison Beamish at the University of British Columbia for her assistance with English language and grammatical editing of the manuscript.

Financial support came from National Natural Science Foundation of China (31370592, 31200461, 31470617 and 31460195) and Forestry industry research special funds for public welfare projects (201404211).

\section{References}

Aerts R, Chapin III FS (2000). The mineral nutrition of wild plants revisited: A re-evaluation of processes and patterns. Advances in Ecological Research 30: 1-68. - doi: 10.1016/S0065-2504(08) 60016-1

Albayrak S, Çamas N (2007). Effects of temperature and light intensity on growth of fodder beet (Beta vulgaris var. Crassa mansf.). Bangla- 
desh Journal of Botany 36: 1-12. [online] URL: http://www.banglajol.info/index.php/BJB/articl e/view/1542

Aubin I, Gachet S, Messier C, Bouchard A (2007). How resilient are northern hardwood forests to human disturbance? An evaluation using a plant functional group approach. Ecoscience 14: 259-271. - doi: 10.2980/1195-6860(2007)14 [259:HRANHF]2.0.CO;2

Caccianiga M, Luzzaro A, Pierce S, Ceriani RM, Cerabolini B (2006). The functional basis of a primary succession resolved by CSR classification. Oikos 112: 10-20. - doi: 10.1111/j.0030-1299. 2006.14107.x

Chai Y, Liu X, Yue M, Guo J, Wang M, Wan P, Zhang $X$, Zhang $C$ (2015). Leaf traits in dominant species from different secondary successional stages of deciduous forest on the Loess Plateau of northern China. Applied Vegetation Science 18: 50-63. - doi: 10.1111/avsc.12123

Chai $Y$, Yue $M$, Wang $M, X u J$, Liu $X$, Zhang $R$, Wan $P$ (2016). Plant functional traits suggest a change in novel ecological strategies for dominant species in the stages of forest succession. Oecologia 180: 771-783. - doi: 10.1007/s00442015-3483-3

Clark DL, Wilson M, Roberts R, Dunwiddie PW, Stanley A, Kaye TN (2012). Plant traits - a tool for restoration? Applied Vegetation Science 15: 449-458. - doi: 10.1111/j.1654-109X.2012.01198.x

Díaz S, Cabido M (2001). Vive la différence: plant functional diversity matters to ecosystem processes. Trends in Ecology and Evolution 16: 646-655. - doi: 10.1016/S0169-5347(01)02283-2

Douma JC, De Haan MWA, Aerts R, Witte J-PM, Van Bodegom PM (2012). Succession-induced trait shifts across a wide range of NW European ecosystems are driven by light and modulated by initial abiotic conditions. Journal of Ecology 100: 366-380. - doi: 10.1111/j.1365-2745.2011.0193 2.x

Elser JJ, Acharya K, Kyle M, Cotner J, Makino W, Markow T, Watts T, Hobbie S, Fagan W, Schade J, Hood J, Sterner RW (2003). Growth rate-stoichiometry couplings in diverse biota. Ecology Letters 6: 936-943. - doi: 10.1046/j.1461-0248.20 03.00518.x

Falster DS, Warton DI, Wright IJ (2006). SMATR: standardised major axis tests and routines, ver 2.o. Web site. [online] URL: http://www.bio. mq.edu.au/ecology/SMATR/

Funk JL, McDaniel S (2010). Altering light availability to restore invaded forest: the predictive role of plant traits. Restoration Ecology 18: 865872. - doi: 10.1111/j.1526-100X.2008.00515.x

Garnier E, Cortez J, Billès G, Navas M-L, Roumet C, Debussche M, Laurent G, Blanchard A, Aubry D, Bellman A, Neill C, Toussaint J-P (2004). Plant functional markers capture ecosystem properties during secondary succession. Ecology 85 : 2630-2637. - doi: 10.1890/03-0799

Grotkopp E, Rejmanek M (2007). High seedling relative growth rate and specific leaf area are traits of invasive species: phylogenetically independent contrasts of woody angiosperms. American Journal of Botany 94: 526-532. - doi: 10.3732/ajb.94.4.526

Güsewell S (2004). N:P ratios in terrestrial plants: variation and functional significance. New Phytologist 164: 243-266. - doi: 10.1111/j.14 69-8137.2004.01192.x
Güsewell S, Gessner MO (2009). N:P ratios influence litter decomposition and colonization by fungi and bacteria in microcosms. Functional Ecology 23: 211-219. - doi: 10.1111/j.1365-2435.20 08.01478.x

Han WX, Fang JY, Guo DL, Yan Z (2005). Leaf nitrogen and phosphorus stoichiometry across 753 terrestrial plant species in China. New Phytologist 168: 377-385. - doi: 10.1111/j.1469-8137.20 05.01530.x

He JS, Wang L, Flynn DFB, Wang X, Ma W, Fang J (2008). Leaf nitrogen: phosphorus stoichiometry across chinese grassland biomes. Oecologia 155: 301-310. - doi: 10.1007/s00442-007-0912-y

Hoffmann WA, Franco AC, Moreira MZ, Haridasan $M$ (2005). Specific leaf area explains differences in leaf traits between congeneric savanna and forest trees. Functional Ecology 19: 932-940. - doi: 10.1111/j.1365-2435.2005.01045.x Kahmen S, Poschlod P (2004). Plant functional trait responses to grassland succession over 25 years. Journal of Vegetation Science 15: 21-32. doi: 10.1111/j.1654-1103.2004.tbo2233.x

Kay AD, Ashton IW, Gorokhova EC, Kerhov AJ, Liess A, Litchman E (2005). Toward a stoichiometric framework for evolutionary biology. Oikos 109: 6-17. - doi: 10.1111/j.0030-1299.2005.14 048.x

Kraft NJB, Valencia R, Ackerly DD (2008). Functional traits and niche-based tree community assembly in an Amazonian forest. Science 322: 580-582. - doi: 10.1126/science. 1160662

Lavorel S, Mclntyre S, Landsberg J, Forbes TDA (1997). Plant functional classifications: from general groups to specific groups based on response to disturbance. Trends in Ecology and Evolution 12: 474-478. - doi: 10.1016/S0169-5347 (97)01219-6

Liu WD, Su JR, Li SF, Zhang ZJ, Li ZW (2010). Stoichiometry study of $\mathrm{C}, \mathrm{N}$ and $\mathrm{P}$ in plant and soil at different successional stages of monsoon evergreen broad-leaved forest in Pu'er, Yunnan Province. Acta Ecologica Sinica 30: 6581-6590.

Matzek V, Vitousek PM (2009). N:P stoichiometry and protein:RNA ratios in vascular plants: an evaluation of the growth-rate hypothesis. Ecology Letters 12: 765-771. - doi: 10.1111/j.1461-0248. 2009.01310.x

McGill BJ, Enquist BJ, Weiher E, Westoby M (2006). Rebuilding community ecology from functional traits. Trends in Ecology and Evolution 21: 178-185. - doi: 10.1016/j.tree.2006.02.002 Mládek J, Hejcman M, Hejduk S, Duchoslav M, Pavlu V (2010). Community seasonal development enables late defoliation without loss of forage quality in low productive semi-natural grasslands. Folia Geobotanica 46: 17-34. - doi: 10.1007/s12224-010-9083-4

Navas ML, Roumet C, Bellmann A, Laurent G, Garnier E (2010). Suites of plant traits in species from different stages of a Mediterranean secondary succession. Plant Biology 12: 183-196. doi: 10.1111/j.1438-8677.2009.00208.x

Reich PB (1995). Phenology of tropical forests: patterns, causes, and consequences. Canadian Journal of Botany 73: 164-174. - doi: 10.1139/b95020

Reich PB, Wright IJ, Cavender-Bares J, Craine JM, Olesen J, Westoby M, Walters MB (2003). The evolution of plant functional variation: traits, spectra, and strategies. International Journal of
Plant Science 164: 143-164. - doi: 10.1086/374368 Suding KN, Lavorel S, Chapin FS, Cornelissen JHC, Diaz S, Garnier E, Goldberg D, Hooper D, Jackson ST, Navas M-L (2008). Scaling environmental change through the community-level: a trait-based response-and-effect framework for plants. Global Change Biology 14: 1125-1140. doi: 10.1111/j.1365-2486.2008.01557.x Vendramini F, Díaz S, Gurvich DE, Wilson PJ, Thompson K, Hodgson JG (2002). Leaf traits as indicators of resource-use strategy in floras with succulent species. New Phytologist 154: 147-157. - doi: 10.1046/j.1469-8137.2002.00357.x Waite M, Sack L (2010). How does moss photosynthesis relate to leaf and canopy structure? Trait relationships for 10 Hawaiian species of contrasting light habitats. New Phytologist 185: 156-172. - doi: 10.1111/j.1469-8137.2009.03061.x Wardle DA, Walker LR, Bardgett RD (2004). Ecosystem properties and forest decline in contrasting long-term chronosequences. Science 305: 509-513. - doi: 10.1126/science.1098778 Warton DI, Wright IJ, Falster DS, Westoby M (2006). Bivariate line-fitting methods for allometry. Biological Review 81: 259-291. - doi: 10.1017 /S1464793106007007

Westoby M (1998). A leaf-height-seed (LHS) plant ecology strategy scheme. Plant and Soil 199: 213-227. - doi: 10.1023/A:1004327224729

Westoby M, Falster DS, Moles AT, Vesk PA, Wright IJ (2002). Plant ecological strategies: some leading dimensions of variation between species. Annual Review of Ecology and Systematics 33: 125-159. - doi: 10.1146/annurev.ecolsys. 33.010802.150452

Wilson PJ, Thompson K (1999). Specific leaf area and leaf dry matter content as alternative predictors of plant strategies. New Phytologist 143: 155-162. - doi: 10.1046/j.1469-8137.1999.004 27.x

Wright IJ, Reich PB, Westoby M (2003). Leastcost input mixtures of water and nitrogen for photosynthesis. The American Naturalist 161: 98-111.

Wright IJ, Reich PB, Westoby M, Ackerly DD, Baruch Z, Bongers F, Cavender-Bares J, Chapin $\mathrm{T}$, Cornelissen JHC, Diemer M, Flexas J, Garnier E, Groom PK, Gulias J, Hikosaka K, Lamont BB, Lee T, Lee W, Lusk C, Midgley JJ, Navas M-L, Niinemets $U$, Oleksyn J, Osada N, Poorter H, Poot P, Prior L, Pyankov VI, Roumet C, Thomas SC, Tjoelker MG, Veneklaas EJ, Villar R (2004). The worldwide leaf economics spectrum. $\mathrm{Na}$ ture 428: 821-827. - doi: 10.1038/nature02403 Yan ER, Wang XH, Zhou W (2008). N:P stoichiometry in secondary succession in evergreen broad-leaved forest, Tiantong, East China. Journal of Plant Ecology (Chinese Version) 32: 13-22.

\section{Supplementary Material}

Tab. S1 - Stand factors, species richness and abundance in four successional stages.

Tab. S2 - Species information in this study.

Tab. S3 - Relationships between leaf traits and successional stage.

Link: Liu_2045@supplo01.pdf 